\title{
Acute Adrenal Hemorrhage in an Elderly Patient
} Yaşlı bir Hastada Görülen Akut Adrenal Kanama

\author{
Demet Acar ${ }^{1}$, Mustafa Gülpembe¹, Nazire Belgin Akıllı1, Saniye Göknil Çalık', Ramazan Köylü¹, Yahya Kemal Günaydın¹, Türker Acar² \\ 'Department of Emergency Medicine, Konya Training and Research Hospital, Konya, Turkey \\ 2Department of Radiology, Mevlana University, Konya, Turkey
}

\section{ABSTRACT}

Introduction: Adrenal hemorrhage is a relatively rare condition that is caused by trauma, stress, sepsis, adrenal tumors, anticoagulation, hemorrhagic disorders, and pregnancy. In acute adrenal hemorrhage, prompt diagnosis and treatment may be life-saving, because acute adrenal hemorrhage may result in acute adrenalin insufficiency and fluid-electrolyte imbalance.

Case Report: Herein we present the case of an elderly patient admitted to the emergency room with right shoulder pain that was diagnosed and treated for adrenal hematoma in a few hours.

Conclusion: Acute adrenal hemorrhage is quite rare and accurate diagnosis of this condition is extremely difficult. Clinicians should be aware of this rare condition and its management in order to accomplish prompt treatment.

Keywords: Acute adrenal hemorrhage, elderly, management

Received:06.11.2014 Accepted: 29.12.2014

Available Online Date: 13.02.2015

\section{ÖZET}

Giriş: Adrenal kanama oldukça nadir görülmekle birlikte travma, stres, sepsis, adrenal tümör, antikoaülan ilaçlar, kanama bozuklukları ve gebelik gibi durumlara sekonder gelişebilir. Akut adrenal kanama adrenal yetmezliğe ve sıvı-elektrolit dengesizliğine yol açabileceğinden acil tanı ve tedavi hayat kurtarıcıdır.

Olgu Sunumu: Burada sağ omuz ağrısı şikayeti ile acil servise başvuran yaşlı bir hastada bir kaç saat içinde tanısı konan ve tedavisi gerçekleştirilen bir adrenal kanma sunulacaktır.

Sonuç: Akut adrenal kanama çok nadirdir ve tanısı da oldukça zordur. Klinisyenler, hızlı tanı ve tedavi için bu nadir hastalığı akılda tutmalıdır.

Anahtar Kelimeler: Akut adrenal kanama, yaşlı, tedavi

Geliş Tarihi: 06.11.2014 Kabul Tarihi: 29.12.2014

Çevrimiçi Yayın Tarihi: 13.02.2015

\section{Introduction}

Adrenal hemorrhage is a relatively rare condition that is caused by trauma, stress, sepsis, adrenal tumors, anticoagulation, hemorrhagic disorders, and pregnancy (1). It is important to determine the etiology for appropriate treatment. Prompt diagnosis and treatment may be life-saving because acute adrenal hemorrhage may result in acute adrenalin insufficiency and fluid-electrolyte imbalance (2). Adrenal hemorrhage may lead to acute adrenal crisis, shock, and death if both glands are affected. The overall mortality rate of acute abdominal hemorrhage is reported to be as high as 15\% (3).

Herein we present the case of an elderly patient admitted to the emergency room with right shoulder pain that was diagnosed and treated for adrenal hematoma in a few hours.

\section{Case Report}

A 74-year-old male was admitted to the emergency room with right shoulder and chest pain lasting for approximately $8 \mathrm{~h}$. He had hypertension and was taking angiotensin-converting enzyme (ACE) inhibitors in combination with thiazide diuretics without any anticoagulant. On admission, his body temperature was $37.1^{\circ} \mathrm{C}$, blood pressure was $240 / 140 \mathrm{mmHg}$, and pulse was regular with a rate of 80 beats/min. Physical examination did not reveal any remarkable finding. Complete blood count and biochemical tests were within the normal limits. Electrocardiography and blood cardiac markers including creatine kinase (CK)-MB, myoglobin, and Troponin I were normal. His blood pressure was controlled with iv glyceril trinitrate infusion. However,

\section{Address for Correspondence/Yazışma Adresi:}

Demet Acar, Department of Emergency Medicine, Konya Training and Research Hospital, Konya, Turkey.

Phone: +90 5336155032 E-mail:dr_demetacar@hotmail.com 
his symptoms did not resolve with the control of blood pressure and im analgesic administration, and thoracic and upper abdominal computed tomography (CT) was ordered. Thoracic CT did not reveal any abnormality, but abdominal CT demonstrated a 6-cm lesion in the right adrenal gland. In addition, there was high-density fluid accumulation in the vicinity of this lesion, compatible with acute hemorrhage. Venography showed a partial defect in blood flow in the inferior vena cava proximal to the right renal vein, considered to be the pressure effect of the hematoma. Selective angiography of the right renal artery established an extravasation in the right surrenal artery originating from the superior branch of the right renal artery, and this artery was embolized with a particular embolizing agent. Control angiography demonstrated total embolization. The patient was subsequently hospitalized in the cardiovascular surgery department for follow-up.

The patient's informed consent was obtained before preparation of this report.

\section{Discussion}

Acute adrenal hemorrhage is quite rare and accurate diagnosis of this condition is extremely difficult owing to its non-specific presentations. The most common symptoms of adrenal hemorrhage at presentation include sudden abdominal, chest, flank, or back pain, nausea and vomiting, hypotension/shock, tachycardia, and fever (4). Anemia, hypotension, or even sudden death may also be the presenting symptoms (5).

The adrenal gland has a rich blood supply from the aorta by 3 arteries that divide into 50-60 branches, the capillary plexus of which drain into medullary sinusoids that form a single central adrenal vein. The pathogenesis of adrenal hemorrhage is multifactorial. Sepsis, disseminated intravascular coagulation, lupus anticoagulant and antiphospholipid antibodies, postoperative period, trauma, and anticoagulation are the main causes of adrenal hemorrhage. On the other hand, the incidence of spontaneous adrenal hemorrhage has been reported to be $0.14 \%-1.1 \%$ (6). Spontaneous adrenal hemorrhage is usually unilateral, involving the right gland, and it typically presents with sudden-onset abdominal or flank pain. In our case, no known etiological factors were present and the clinical course resembled that of spontaneous hemorrhage.

Some imaging modalities have been shown to be useful in differential diagnosis, and if there is a clinical suspicion of adrenal hemorrhage, advanced imaging techniques including $\mathrm{CT}$ should be ordered immediately. CT is highly sensitive and specific in the diagnosis of adrenal hemorrhage and it may be reveal adrenal hemorrhage as a non-homogenous mixed-density adrenal mass with extensive perirenal changes, a rapidly enlarging adrenal mass, or extensive retroperitoneal hemorrhage (7).

The adrenal gland classically has 3 arterial sources (superior, middle, and inferior adrenal arteries). A variety of indications exist for adrenal artery embolization, including palliative measures for oncological cases such as pain relief, reduction of tumor bulk, and preoperative reduction of tumor vascularity. On the other hand, emergency embolization is indicated to preserve hemostasis in ruptured tumors, to suppress excess adrenal hormone production, to treat traumatic adrenal artery injury, and to occlude adrenal artery aneurysms (8). Similar to our case, embolization has been reported to be successful in many adrenal hemorrhage cases with different etiologies (9).

In the management of adrenal hemorrhage, supportive treatments, including volume resuscitation, preserving electrolyte balances, blood transfusion, and observation, are crucial $(5,10)$. Although surgery may be necessary in traumatic cases or cases of hemorrhage due to an underlying tumor, in cases of ongoing hemorrhage, embolization may be a life-saving measure (9)

\section{Conclusion}

Clinicians should be aware of adrenal hemorrhage and its management in order to accomplish prompt treatment of this rare condition.

Informed Consent: Written informed consent was obtained from the patient.

Peer-review: Externally peer-reviewed.

Author Contributions: Concept - D.A.; Design - D.A.; Supervision - D.A., B.C.; Materials - M.G.; Data Collection and/or Processing - N.B.A., S.G.Ç.; Analysis and/or Interpretation - R.K., Y.K.G.; Literature Review - D.A.; Writer - D.A.; Critical Review - T.A.

Conflict of Interest: The authors declared no conflict of interest.

Financial Disclosure: The authors declared that this study has received no financial support.

Hasta Onamı: Yazılı hasta onamı bu olguya katılan hastadan alınmıştır.

Hakem değerlendirmesi: Dış bağımsız.

Yazar Katkıları: Fikir - D.A.; Tasarım - D.A.; Denetleme - D.A., B.C.; Malzemeler - M.G.; Veri toplanması ve/veya işlemesi - N.B.A., S.G.Ç.; Analiz ve/veya yorum - R.K., Y.K.G.; Literatür taraması - D.A.; Yazıyı yazan - D.A.; Eleştirel Inceleme - T.A.

Çıkar Çatışması: Yazarlar çıkar çatışması bildirmemişlerdir.

Finansal Destek: Yazarlar bu çalışma için finansal destek almadıklarını beyan etmişlerdir.

\section{References}

1. Xarli VP, Steele AA, Davis PJ, Buescher ES, Rios CN, Garcia-Bunuel R. Adrenal hemorrhage in the adult. Medicine (Baltimore) 1978; 57: 211-21. [CrossRef]

2. Vella A, Nippoldt TB, Morris JC 3rd. Adrenal hemorrhage: a 25-year experience at the Mayo Clinic. Mayo Clin Proc 2001; 76: 161-8. [CrossRef]

3. Tritos NA. Adrenal Hemorrhage. E Medicine 2007. http://emedicine. medscape.com/article/126806-overview. [CrossRef]

4. Ahmad S, Abdulqawi R, Ashawesh K. Massive retroperitoneal adrenal haemorrhage as the first manifestation of a lung cancer. Ann Acad Med Singapore 2008; 37: 615-6. 
5. Marti JL, Millet J, Sosa JA, Roman SA, Carling T, Udelsman R. Spontaneous adrenal hemorrhage with associated masses: etiology and management in 6 cases and a review of 133 reported cases. World J of Surg 2012; 36: 75-82. [CrossRef]

6. Gavrilova-Jordan LP, Edmister WB, Farrell MA, Watson WJ. Spontaneous adrenal hemorrhage during pregnancy: a review of the literature and a case report of successful conservative management. Obstetrical and Gynecological Survey 2005: 60: 191-5. [CrossRef]

7. Shah HR, Love L, Williamson MR, Buckner BC, Ferris EJ. Hemorrhagic adrenal metastases: CT findings. J Comput Assist Tomogr 1989: 13: 77-81. [CrossRef]
8. Fowler AM, Burda JF, Kim SK. Adrenal artery embolization: anatomy, indications, and technical considerations. AJR Am J Roentgenol 2013; 201: 190-201. [CrossRef]

9. Patel A, Downing R, Vijay S. Spontaneous rupture of the adrenal artery successfully treated using the endovascular approach: a report of 2 cases. Vasc Endovascular Surg 2013; 47: 124-7. [CrossRef]

10. Marti JL, Millet J, Sosa JA, Roman SA, Carling T, Udelsman R. Spontaneous adrenal hemorrhage with associated masses: etiology and management in 6 cases and a review of 133 reported cases. World J Surg 2012; 36: 75-82. [CrossRef] 